\title{
Contractual Transaction: How Renting a Uterus Makes the Human Body a Commodity in Nepal
}

\author{
Madhusudan Subedi
}

\begin{abstract}
The sperm came from Israel. It was frozen in Thailand. The egg donor from South Africa. The embryo traveled to Nepal where an Indian woman was the surrogate mother. Nine months later as the Greengolds were headed to a Kathmandu hospital where the mother had given birth, the earthquake struck... One day when the Greengolds tell their little Yaari about how he was born in the middle of a terrible earthquake, it will be a unique and thrilling story. (Sandip Roy: April 30, 2015).
\end{abstract}

\begin{abstract}
The issue of surrogate motherhood has started public debates in Nepal. With surrogacy a child becomes the object of a legal transaction, while the surrogate mother is used, in effect as an incubator, and the hospital declares commissioned parents' name of a newborn child. The poor women in low-income countries have been used as means to compensate for the reproductive deficiencies of high-income infertile parents. Do purchasing cheaper services, receiving surrogates easier, and having the possibility of gender selection, all in the poor countries, support 'surrogacy tourism'or is it a kind of exploitative relationship? Until today, Nepal's laws do not have any specific provision to deal with surrogacy and, therefore, it is urgent to address the challenges with commercial surrogacy and establish a precise legal policy.
\end{abstract}

Keywords: Surrogacy, surrogacy tourism, commodity surrogacy legislation, body as a commodity, parenthood and the market, Nepal 


\section{2| Madhusudan Subedi}

\section{Introduction}

There have been profound shifts in the conceptualization of the categories of conception, reproduction, and parenthood. Increasing infertility rates and also in the demand for reproductive technologies have challenged some of the family's traditional functions. With the advances in reproductive medicine, couples that in the past would not have been able to reproduce are now offered an opportunity to have children (Wallbank, 2002). The introduction of new reproductive technologies has questioned the status of motherhood and parenthood. In the traditional family, the genetic, gestational, and social mothers are one and the same. But recently, genetic and gestational motherhood has become separable through new reproductive technologies such as surrogate motherhood (Metin, 2011).Asurrogate mother is a woman who becomes pregnant, carries, and delivers a child on behalf of another couple, the commissioning parents, and at birth hands over this child to this couple. In this article I discuss a few concerns in relation to surrogacy in Nepal, focusing on the potential surrogate's difficulties and provision of the legislation for surrogacy. I argue that economic globalization aggravates women of low-income countries to supply surrogacy services. A pregnant woman is supposed to perform various risks for the benefits of a commissioning couple, working as a survival strategy and a temporal occupation for livelihood. Without proper legal provision surrogacy will be counter-productive in Nepal. This article also opens many lines for further inquiry on the supremacy of the market forms, and of social relations' fetishizing within medical technology in low-income countries.

\section{Parenthood and Renting a Uterus: Commercial or Altruistic?}

The sociological evidence for the families' changing structure and functions are the result of the interplay between individualism and the market economy. These changes are due to the increasing legitimacy of self-interest as a criterion for decisions as opposed to the interest of a larger collective. These changes are related to a context of competing values, personal choice and freedom, economic development, and individual human rights. The fact that people get married at an older age and easily available contraceptives have increased the proportion of the population who are unmarried but sexually active. Cohabitation is becoming more common and marriage no longer signifies a solid commitment to a lifetime 


\section{3| Madhusudan Subedi}

relationship (Haralambos and Heald, 1980). Single-parent families are increasingly due to a higher divorce rate (Pfeifer and Sussman, 1991). Traditional obligatory natures of family roles have been transferred to various social institutions. Parenthood and parenting roles, among others, have changed substantially.

There are five possibilities for a person to claim parenthood: the woman who contributes ovum (genetic mother), the woman who gestates the child (gestational mother), the intending mother (social mother) who will raise the child and may also gestate the child, the sperm donor (genetic father), and the intended father (social father) who will raise the child. This reality fragments the reproductive function of marriage (Edwards, 1991). It separates sex from reproduction, motherhood from pregnancy, and the unity of one couple in the involvement of a third person within the potential family relationship (Iona Institute, 2012). Surrogate motherhood represents a radical departure from traditional views of motherhood and family. It can also be argued that in the post-modern society, the traditional functions of the family have been questioned. New assisted reproduction techniques have grown into a transnational industry.

Families created by surrogacy differ from the traditional families in two important ways (Wallbank, 2002). First, the gestational mother and the social mother are not the same. Although this also is true of adoption, surrogacy differs from adoption in that the pregnancy is created with the deliberate intention of the surrogate mother handing over the child to the commissioning couple. Second, in the case of partial surrogacy, the child is genetically unrelated to the commissioning mother, and where a donated embryo is used, the child is genetically unrelated to both commissioning parents.

Surrogacy is a contractual deal between a surrogate woman and the intended parents in which the surrogate agrees to get impregnated with the intension of carrying the child to full term and handing it over after birth to the intended parents. There are two types of surrogacy, traditional and gestational. The traditional type of surrogacy involves the surrogate mother being artificially inseminated with the sperm of the intended father or sperm from a donor when the sperm count is low. In gestational surrogacy, the surrogate mother has no genetic relationship to the offspring. Eggs and sperm are extracted from the donors and in vitro fertilized and implanted into the uterus of the 


\section{4| Madhusudan Subedi}

surrogate. In either the case the surrogate's own egg will be used. Genetically the surrogate becomes the mother of the resulting child. In general, intended parents' name is put on the birth certificate.

There are various situations in which a couple or an individual may choose surrogacy for begetting the child and become an intended parent. First, inability to conceive due to physical problems, diseases or infertility which is not amenable to treatment. Second, physical problems that make it impossible for a woman to carry a pregnancy to viability or pregnancy that is life threatening. Third, presence of a genetic disease that represents a significant risk of creating abnormalities. Forth, surrogacy can be chosen to beget a child for a single parent or parent in the case of a homosexual couple. Finally, the female of the intending parents is unwilling to undergo pregnancy because of her career or any other reasons. In the typical circumstances, a surrogate mother conceives, carries the child for nine months, gives birth, then hands over the child to the intended parents, and relinquishes her parental rights. The surrogate mother and intended parents, before conception or immediately after birth, consciously decide to hand over the child from the gestational mother to the intended couple. In surrogacy, contrary to adoption, a child is created after a surrogacy arrangement in order to satisfy the commissioning couples' needs.

Surrogate arrangements may be made with or without payment to the surrogate mother. 'Commercial surrogacy' is the term to describe an agreement where payment is made to the surrogate mother. Commercial surrogacy is a blooming activity in several countries, and numerous agencies profit from the suffering of infertile couples and women's vulnerability. In many developing countries hospitals advertise for low-cost surrogacy; the price of a baby in India may be one fourth of the price in California (Iona Institute, 2012). However, it is hard to document the payment. The payment contract raises inappropriate coercion of vulnerable women and is an insult to human dignity. The contract, in general, is articulated the other way around, for example, that the surrogate mother will be financially reimbursed for pregnancy-related medical expenses and eventual complications, travel cost, antenatal visits, home-help expenses, etc.

In recent decades several low and middle income countries have created advanced medical infrastructure in cities that are designed to appeal an increasing number of people from higher income countries. 


\section{5| Madhusudan Subedi}

The health care cost in higher income countries is high and in many cases the processes become too lengthy, and sometimes illegal. In such cases they travel to lower income countries for procedures such as surrogacy that may not be available in their home country, or may not be covered by their health insurance. Having the ability to cover the costs for travels and the procedure, people look for services in low income countries.

'Altruistic surrogacy' is the term to describe the arrangement where money is not paid to the surrogate mother. Such altruistic agreements are often referred to in the literature as being made between friends and relatives. This kind of surrogacy is similar to kidney donation for family members and nearest relatives; donating a uterus temporarily to obtain a pregnancy. The proportion of altruistic surrogacy would be very nominal, and many people would not disagree with such an arrangement.

However, the terms 'commercial' and 'altruistic' are not free of ambiguity. For example, a paying arrangement for surrogate mother's medical travel and home-help expenses may have blurred boundaries. Likewise, parties entering a surrogacy agreement that provides payment to the surrogate mother does not necessary mean that the motivation behind the agreement is not altruistic. Further, if the surrogate mothers want to give the 'gift of life', they probably would rather support their closest relatives than foreign couples. In the lower-income countries like Nepal, taking into consideration some important social variables like age, income, occupation, expectation for the future, and family relations, I am sure that money would be the first reason for becoming a surrogate, and last would be for altruistic reason.

Surrogates are motivated primarily by financial gain. A surrogate has to compromise in a number of activities, such as for instance, obligatory abstention from sexual intercourse from the time insemination begins until a pregnancy has been confirmed. Pande (2010), looking at the unique case of India where commercial surrogacy has become a survival strategy and a temporary occupation for some poor rural women, argues that commercial surrogacy is a form of labor. Here is an example of becoming a surrogate:

I am doing this basically for my daughters; both will be old enough to be sent to school next year. I want them to be educated, maybe become teachers or air hostesses. 


\section{6| Madhusudan Subedi}

I don't want them to grow up and be like me - illiterate and desperate. I don't think there is anything wrong with surrogacy. But of course people talk. They don't understand that we are doing this because we have a compulsion. People who get enough to eat interpret everything in the wrong way. (Pande, 2010, p. 302)

Quoting another case of a surrogate mother, the author writes:

I don't think there is anything wrong with surrogacy. We need the money and they need the child. The important thing is that I am not doing anything wrong for the money - not stealing or killing anyone. And I am not even sleeping with anyone. (Pande, 2010, p. 299)

Some families look at surrogacy not as the individual woman's choice or work but as a 'team effort' made by the entire family to improve the members' financial situation, for instance, to build a house for the family. The family members feel cheated and use the language of morality and moral boundary to affirm their dignity and reduce the stigma attached to surrogacy:

Even though everyone delivers one and we delivered two babies - still we got the same rate. They should have paid us more. That's why we decided we don't become surrogates again. We lost our respect in society and did not even get paid enough for it. (Pande,2010, p. 303)

Ahmari Tehran et al. (2014, p. 475) highlights the complication of pregnancy and describe the case of the hospitalization of a 29 year old Iranian surrogate. They write:

I was engaged in a terrible situation. In addition to emotional problems, I faced a medical problem too. I was hospitalized due to bleeding in early weeks. I was worry about my health. In addition, excessive worry of commissioning couple annoyed me too. Furthermore; I was concerned about my money because if the baby had been aborted I could not have received the agreed money.

From the quotes above, it is clear that the women who work as surrogates in India and Iran are engaged because they need money. The situation of Nepali surrogates is worse than in these countries. Once they remove themselves from the surrogate's life, the intended 


\section{7| Madhusudan Subedi}

couples usually do not consider to provide them with any longterm care and support. Further, longitudinal studies on surrogate mothers are needed, and this should also address the wellbeing of the surrogate's own children.

Sexana et al. (2012, p. 212), highlighting the Indian context, write about this situation:

If we look upon the problem of surrogate mothers, things are even worse and unethical. The poor, illiterate women of rural background are often persuaded in such deals by their spouse or middlemen for earning easy money. These women have no right on decision regarding their own body and life...After recruitment by commercial agencies, these women are shifted into hostels for the whole duration of pregnancy on the pretext of taking antenatal care... These women spend the whole tenure of pregnancy worrying about their household and children... The worst part is that in case of unfavorable outcome of pregnancy, they are unlikely to be paid, and there is no provision of insurance or post- pregnancy medical and psychiatric support for them. Rich career women who do not want to take the trouble of carrying their own pregnancy are resorting to hiring surrogate mothers. There are a number of moral and ethical issues regarding surrogacy, which has become more of a commercial racket, and there is an urgent need for framing and implementation of laws for the parents and the surrogate mother.

What would happen if the baby carried by a surrogate mother is born with a disability? This is theoretically and medically possible. Is there a law to ensure that a contracting mother adopts the disabled surrogate baby? It would be unfair in such circumstances for the surrogate mother to be asked to bring up the baby (Iona Institute, 2012).

Further, a clear arrangement is required for financial support of the surrogate child if the commissioning couple dies before the child's delivery, or the intended parents get divorced and none of them are willing to take care of the delivered child so as to avoid injustice to the child. A clear guideline should be developed so that the child shall be assumed to be the legitimate child of the married 


\section{8| Madhusudan Subedi}

or unmarried couple, single parent with all the attached rights of parentages, support and inheritance. Further, a measure should be made compulsory for prospective parents to document that any infant born to a surrogate mother will have automatic citizenship in their home countries, thus attempting to avoid messy legal battles.

\section{Commodification of Parenthood}

A commodity is a product that is bought and sold. Commodities are things that are useful, or that satisfy human needs. Although a commodity is useful for the person who buys it because it satisfies some needs, it is also useful for the person who sells it because its yielded value exceeds the cost of the labor and material necessary to produce it, either in the form of other commodities or money (Sammond, 2007). Industrialization has accelerated in a series of rapid changes in the organization of people's daily life. The population has shifted from rural to urban settings, and cities have grown exponentially. Subsistence production in the home has been replaced by purchasing those commodities. This transition has come to be called the "commodification of everyday life" or the rise of "consumer culture" (Ritzer, 2000).

Women consistently emerge as specialized targets of commodification, often being valued for their reproductive potential. Male bodies may also be commodified but female bodies dominate scholarly discussion. In the uneven global capitalistic trans-nationalization of sexual reproductive labor, women's bodies are considered as parts of the global form of reproductive labor (Acero, 2009). Surrogacy motherhood is an example of the female bodies' commodification and their reproductive capabilities. Advertisement on the web detailing the desired characteristics of surrogates, for instance, intelligence, beauty, manners, schooling, body size, and poise, over-score certain characteristics of female bodies (Sharp, 2000).

Creating a market for gestational and genetic services surrogate mothers are treated like a 'tradable commodity', commodification and 'devaluation of parenthood'. Monetary surrogacy reduces women's bodies into commodities and a means for production (Metin, 2011). In general, within surrogacy arrangements, the surrogate is treated as a machine whose services can be exchanged for money. Once the babies are delivered, the surrogates' purpose is served. Women's body, especially the uterus, is compared with a 'golden plate' and the baby with a 'golden egg'. The growing prevalence of gestational 


\section{9| Madhusudan Subedi}

surrogacy has introduced a host of new legal and social questions. It is taken more like a business or a paid job. Some would put it more negatively, using terms like 'reproductive prostitution', 'baby trade', 'selling body and parts', 'renting a uterus', 'contract pregnancy', 'incubatory servitude', etc. (Sharp, 2000). Little attention has been given to socio-cultural concerns.

The fundamental objective of surrogacy is to fulfill the desire of intended parents, to have a child and raise the child as their own. Due to generally negative attitudes towards surrogacy, the surrogate mother may not receive as much social support as other mothers during pregnancy and this could cause them to be more vulnerable than they otherwise would be.

It is also important to explore the motivations of the surrogate mothers. My assumption is that surrogates in Nepal are financially desperate or needy, and that they are exploited or coerced by the dalals (brokers) in some way to turn to surrogacy as a final economic resort. Some may argue that paid surrogacy is not fundamentally different from other kinds of jobs where people are motivated by earning money while being employed by those wealthier than themselves. Because of the economic differences, I argue, and it is very clear, that the surrogate and intended parents constitute exploitative or coercive relationships.

\section{Dynamics of the Hospitals, the Intended Parents and the Surrogate}

The production of medical knowledge and its consumption, in contrast to the 'pure' objects produced in the laboratory, have always involved the citizens as well as the subjects in a much more direct manner than other kinds of scientific knowledge. This is partly because the tension between the experimental and the therapeutic, while making new innovations in medical science possible also can lead to unacceptable risks for the patients (Das, 2000, ScherperHuges, 2001). The question of the subject's status becomes integral to the production of knowledge rather than being something which influences it from outside. For example, in countries such as Nepal the demand for human organs has led to the development of black markets in organ procurement. These new kinds of markets belong to the informal economy in which effective legislative and administrative control is virtually absent. 


\section{0| Madhusudan Subedi}

Surrogacy is a collaborative reproduction. Brokers, individuals, and clinics advertise and sell sperms, eggs, and gestating surrogate services in a competitive marketing. It is a highly profitable enterprise. Affluent infertile persons shop for sperms, eggs, and womb services in a competitive market with fluctuating prices. Brokers advertise and search for donors to recruit them for a profit (Callahan, 2014). If a woman is offered a relatively great deal of money, she will be tempted to sell her physical resources and suffer the consequences. If money is involved, a person is reduced to being a means to fulfill another's desire, and exploitation follows. The poor women in lowincome countries are targeted in the gestational surrogacy market. Women's identity as an integrated whole person is threatened of being reduced to a supplier of parts. When a significant amount of money is invested in a transaction, it will probably be expected that the baby should be good-looking and that he/she should achieve social and economic success. There has been little critical analysis of the morbidity and the psychosocial problems of surrogate mothers who sell their reproductive capacities. The poor will need money while the rich can offer to pay.

Compensating the surrogate mother by the intended parents is the key issue in surrogate motherhood. It should be very clear that payment must not be made contingent on the delivery of an 'acceptable product' - a live-born, healthy child. Rather payment should be considered as compensation for the surrogate mother's time and effort, her initiating and carrying the pregnancy, her participation in labor and delivery, her acceptance of the risks of pregnancy and child birth, and her possible loss of employment opportunities (ACOG, 2008).

Surrogacy arrangements often take place between parties with unequal power, education, and economic status. Independent but transparent legal representation and counseling are important. A standard fee must be paid to the surrogate mother. Intended parents and surrogate mothers have both divergent and common interests. The hospitals and qualified doctors' team should closely examine all reproductive issues related to surrogacy, including medical, ethical, legal, and psychological aspects.

Commercial surrogacy is a booming activity in several countries. Numerous agencies profit from the suffering of infertile couples and the vulnerability of women. They charge a very high fee to select 


\section{1| Madhusudan Subedi}

surrogate mothers, and if necessary, egg donors. After a few intrusive recruitment processes, agencies certify that they select only women without medical or judicial background. This is a tricky ethical issue involving wealthy couples paying comparatively poorer women to bear their children.

Commercialization of motherhood through surrogacy is lucrative, but raises social, cultural, economic, and political questions. This probably explains why Nepal's private hospitals and the government are so hush-hush about it. We must be careful not to allow surrogate mothers to be exploited as baby producers (Dahal, 2015). In the absence of a proper law it can lead to trafficking and women can be forced to go through it for the money.

\section{5. 'Renting Wombs, Dirty Work': A Stigmatized Form of Labor}

In general, the surrogate is treated as a 'machine' or a 'reproductive vessel' whose service can be exchanged for money. Some people may argue that the surrogacy might be a better option for the women than unemployment but, for many women, it also might be a new coercive option.

In some cultures surrogates are described as 'true-angels' who 'make dreams happen' but this is also surrounded by controversies about the ethics of 'selling motherhood' and 'renting wombs' and that this 'dirty work' and occupation likely will be perceived as degrading (Pande 2010, p. 298). Women working as surrogates in Nepal live in a context where their families, the media, and medical professionals attach a variety of meanings to surrogacy and to the surrogates' position. During my informal discussions with students, university teachers, professionals, and housewives many, except some nurses, equated surrogates to sex workers, as described by Pande (2010, p. 298):

In India, however, the surrogates face a great deal of stigma. As a consequence, almost all the surrogate mothers in this study kept their work a secret from their communities and very often from their parents. Typically they hide in the clinic or take temporary accommodation in the surrogate hostels during the last months of pregnancy. Some told their neighbors that the baby was their own and later claimed to have miscarried. 


\section{2| Madhusudan Subedi}

One of the most interesting aspects of the surrogate's perception of the fetus she is carrying is that it is not her child. According to a liberal argument, the women can best judge and keep their self-interest independently. Surrogate mothers can earn money by selling their reproductive capacities at the market like any legitimate occupation rather than getting poorer (Metin, 2011). The individualistic assumption that all choices are free is shallow and misleading. Surrogate mothers can offer a solution for a couple whose marriage may be endangered due to infertility and, therefore, may serve the promotion of the family.

Literature says that the surrogate mothers are financially and emotionally unstable, with little education, likely to be young, single, and with a minority background. It is assumed that they will not make proper informed decisions which they later will regret and suffer long-term psychological damages (Peng, 2013). A qualitative study on 'Emotional Experiences in Surrogate Mothers in Iran' by Ahmari Tehran et al. (2014, p. 475) found that the women had serious worries and concerns about informing their relatives and friends. The researchers quote the study participants' response regarding the cultural and economic issue as:

None of my family members and relatives did know that I had rented my uterus expect my mother and sister. I was very worried. I did not know if my mother-in-law found out, how she would react. I had to undergo this action because my husband was in a bad financial situation but I did not know what should I say to others.

All the expenses including insurance of the surrogate's medical bill and other reasonable expenses related to pregnancy and childbirth should be borne by intended parents. A surrogacy contract should include life insurance coverage for the surrogate mother. The surrogate mother should also receive monetary compensation from the couple or individual as the case may be for agreeing to act as a surrogate. It is felt that in order to save poor surrogate mothers from exploitation, banks should directly deal with them, and a minimum remuneration to be paid to the surrogate mother should be fixed by law.

\section{The Surrogacy Issue in Nepal}

The devastating earthquake in Nepal on 25 April, 2015 uncovered 


\section{3| Madhusudan Subedi}

many harsh realities of life in Nepal, including surrogacy. The hospitals had to face challenges and doctors operated in the tents while aftershocks kept coming. After the rescue work, an Israeli Boeing 747 flew back to the Ben Gurion International Airport carrying 15 babies intended for Israeli parents, all born by surrogate mothers in Nepal. None of the surrogate mothers were allowed to travel. The earthquake accidentally exposed a business entity in Nepal. The practice of renting a uterus and the private sector's role in commercialization of surrogacy have now received media attention.

The complexity of this story brings to light many social, economic, medical, and ethical issues. Though commodification of the womb is not a new issue, there are recent dynamics around surrogacy in Nepal to legitimatize the process. When this market-driven globalized activity became more public, I decided to write and address some agendas.

Nepal, especially the Kathmandu Valley, is a favored destination due to its relatively sophisticated medical infrastructure and affordable rates. It is urgent to investigate the cross-border black market for organs and transplant surgery. The rapid globalization of money, images, goods, and desires has markedly changed the scale and nature of commodification also in Nepal. Social transactions once largely confined within an intimate, non-commercial domestic economy have increasingly shifted into the market economy (Liechty, 2005). Patterns of social structure in caste, class and gender relations, family forms and relations are linked to a capitalistic modernity, especially in the major towns. These towns are becoming a destination for business, shopping, gambling, prostitution, and human and organ trafficking, and currently a chief place for surrogacy in the international market.

Although Nepal does not have law that regulates surrogacy, it is becoming the destination for foreigners seeking to have children through surrogate mothers. Surrogacy service in Nepal is motivated by the desire to circumvent domestic laws and regulation, and to take advantage of a cost saving process. In 2014, the government of Nepal allowed foreign women to serve as surrogate in Nepal. It attracted foreign couples due to relatively cheaper services compared to higher income countries. It raised, however, many constitutional and legal questions. 


\section{4| Madhusudan Subedi}

Media reports on commercial surrogacy have told about Nepali women flocking to India to offer becoming surrogate mothers to rich people, especially foreigners or non-resident Indians (The Times of India, 2011). Dahal (2015) argues that commercial surrogate motherhood is moving to Nepal because of restriction in India. She argues that after the tightened rules on commercial surrogacy, foreigners seeking such services have started trickling into Nepal where the rules are murky and the regulations weak. The government of Nepal decided recently to allow foreigners to come for this purpose, arguing that this would promote medical tourism in the country. The government's decision makes it easy for foreigners to be surrogate parents by processing exit permits for their babies born in Nepal. It is also stated by various media that surrogate mothers are misrepresented as Indians and Nepali women are used for surrogacy. These activities have raised some key issues about surrogacy's social impact on family structure and relationships, the nature of motherhood and parenthood, concerns about the exploitation of women, management of uncertainty when the intended parents divorce or they decline to accept the child because the baby is born with a medical condition or disability, and the role of law in this unfamiliar terrain.

A nurse working in a private hospital in Kathmandu said, "brokers are playing key role to facilitate the surrogacy in Nepal. They have national and international linkages with prospective parents, possible surrogate mothers, qualified facilities and surgeons. They arrange air travel and accommodation. They also provide comparison costs." Similarly, a doctor working in a sophisticated hospital said: "Established private hospitals attract clients from high income countries by demonstrating the quality and safety standards they provide. They encourage taking advantage of the significant cost-saving in health care available in Nepal, including surrogacy." Both the nurse and doctor admitted the poor legal frameworks addressing the malpractice in Nepal. From these statements it is clear that foreigners are motivated by the desire to obtain a surrogate child that are unavailable domestically due to legal constraints. The prime beneficiaries are limited to intended parents, the hospitals and doctors, and the brokers. Facilities are not obligated to provide a fair amount of money to the surrogate mothers and compromise their health status and cultural concerns.

The current law in Nepal states that the mother of a child is the one 


\section{5| Madhusudan Subedi}

who gives birth to the baby. However, there are political interests to change the law in favor of surrogacy in Nepal (see Annex I with two letters issued by Chief Secretary of Nepal, and Annex II with the Supreme Court's decision). These interest groups want to develop a model of surrogacy close to the liberal market model to be managed by private commercial agencies that regulate agreements according to their own criteria and without state interference.

Many social media in Nepal have argued that some private hospitals in Kathmandu are playing an active role for doctors, nurses, and brokers (both male and female) who are recruiting surrogate women. For international couples, hiring the surrogates in Nepal provides substantial cost-savings. The hospitals run hostels where the doctors and the commissioned couples can monitor the surrogates' activities. The social media charge that only a small fraction of the fee paid by the parents actually reaches the surrogate mothers; most of the money goes to the agencies that arrange the surrogacies and to the hospitals.

The Ministry of Health and Population writes a recommendation based on the birth certificate with a DNA document issued by the hospital, thus facilitating the intended parents to apply for a passport at the resident embassy. Legal scholars in Nepal argue that surrogate motherhood causes legal, social, psychological, and ethical problems, and that there is no guarantee that this practice presents more benefits than harm.

It is reasonable to ask how prevalent surrogacy is if we are to make a realistic evaluation of its impact on Nepal's families and larger society. Most of surrogacies are conducted in private hospitals. Although it is difficult to ascertain statistical data because of social and, sometimes, legal challenges, a fair number of babies have been born from surrogacy, and it is assumed that the annual number will increase rapidly, at least doubling annually the next several years.

The purpose of availing the services of a surrogate mother is to beget a healthy child. For this reason, a surrogate mother is bound to follow various duties during the initiation of surrogacy and subsequent pregnancy, so that a baby is born without any complication. Thus, the intended parents have a right to impose restriction upon the behavior and the activities of the surrogate mother during this period. Eligibility criteria are one of the important issues in this regard. If 


\section{6| Madhusudan Subedi}

an unmarried woman will serve as a surrogate it would violate the culturally prescribed definition and norms about kinship, the status of the child that is born, and the family.

As already mentioned, surrogacy in Nepal is not governed by laws. The surrogate motherhood agreement will only be valid if the following prerequisites, but not limited to, are made:

-. The surrogate mother must confirm the agreement, and all the involved parties should be living in Nepal. The agreement must be in writing and signed by all involved parties.

- The agreement must be in line with the law of the land, and a legal mechanism needs to confirm the surrogacy agreement before the surrogate mother may be impregnated.

- The commissioning mother must be permanently medically unsuited or incapable of giving birth to a healthy living child. The commissioning parents must be lawfully married and jointly enter the surrogacy agreement.

- The commissioning parents must be physically, financially, and psychologically competent to enter the agreement, must be suited to parenthood, and must understand and accept the legal consequences involved.

- The surrogate mother must be physically and psychologically suitable, should take consent from her husband (if married), and she should have full medical aid coverage.

- The interest of any existing children of the surrogate mother should always be protected.

- In the case of divorce, the commissioning parents will still be the parents. The surrogate mother would have the first right to keep the child in the event of both the commissioning parents' death.

- A critical question to be solved is if the surrogate mother dies as a result of pregnancy; who would then be responsible for taking care of her children and family?

The production of a child is a central concern for both men and 


\section{7| Madhusudan Subedi}

women in Nepal. According to the common understanding, conception is expressed in terms of the 'seed' and 'field' analogy (Subedi, 2001). A man is said to plant the seed, and the woman is like the field in which it is planted. The seed determines the kind of plant that will grow, while the field nourishes the plant but does not determine the kind. Sex is said to take place inside the woman but outside the male. Similar cultural constructions are prevalent in other social worlds (e.g. Delaney 1991, Nichter and Nichter 1996). However, with the gradual infiltration of biomedicine and medical sciences, some people disagree and argue that this is not the case.

Except among family members and close neighbors, pregnancy passes unnoticed for a long time. Furthermore, Nepali women are socialized at a very early age concerning the situation, circumstances, and society's expectations regarding the sexual relationships. The uterus is considered to be a sacred object surrounded by rules protecting this object from being profaned (Subedi, 2010), rules governing who may approach the sacred, and what may and may not be done during such an approach (Durkheim, 1985). If these rules are followed, the sacred will not lose its sacredness, but if they are violated, there is danger of the sacred being profaned.

The surrogacy in Nepal must be ethically acceptable, without doing harm to the surrogate mother. Important values in the Nepali society at large need to be respected and encouraged. Till date, the government of Nepal has no legal obligation and rarely understands its moral obligations. For many years, India - where costs are low but the standard of medical care is generally high - was the preferred surrogacy options, but a legal change there in 2013 prevented from engaging surrogate mothers. It is assumed that surrogacy in India and Nepal is managed by brokers (dalals) working under political protection, and that there is a nexus between them and private hospitals. It is a question of supply and demand; there is a demand in rich countries for babies, and there is a supply of poor families in developing countries willing, and sometimes forcing, their women to become surrogate mothers (Dahal, 2015). Wealthy prospective parent(s) have a demand for women who will carry their child. This demand has led to a growth in the supply of women who are willing to rent out their wombs. Kathmandu can be a popular site for medical tourism for international couples hiring surrogates at a nominal cost. Economists use the term "race to bottom" to describe companies who move their headquarters to foreign countries in order to pay less 


\section{8| Madhusudan Subedi}

taxes than they would in Western countries. These types of trends in the surrogacy market trouble us (Mcbride, 2015).

\section{Revisiting Research Method(s): Translating Findings into Policy and Practice}

The production of knowledge is not a value-free undertaking. It is important to define the underlying values in the choice of research themes and methods. The central aim of research should be, in my opinion, to produce knowledge designed to improve the economic and social conditions and sustainable livelihoods of the population concerned without compromising its physical, social, and mental wellbeing.

Globalization is the mechanism for the rule of international investors and transnational corporations that no longer can be controlled by weaker countries. It has created new forms of global stratification in which some individuals, communities, countries or regions become integrated into the global network of power and prosperity, while others are excluded and marginalized. Such differences make it clear that social research needs to look not only at general aspects of globalization but also at specific factors that have varying effects and reactions at the national and local levels.

The research arising from the top-down approach include use of official social statistics, short studies by experts, and survey methods using questionnaires with multiple-choice questions. Such data may reflect biases built into the data collection process. Researchers on short visits tend to rely on information from people in power positions (particularly men) and may not perceive the problems, needs, and wishes of other groups (Chambers 1997, Castles 2001, Denzin and Lincoln, 2005). Structured questionnaires to a great extent limit possible answers, giving little opportunity for presenting new information or divergent views. Top-down methods often ignore the social situation and needs of local groups, especially the poor and women, who have little access to political power. These groups are seen as obstacles to progress, to be dealt with either through public order measures or educational strategies designed to foster willingness to accept change (LeCompte and Schensul 1999, Schensul et al. 1999, Castles, 2001).

Furthermore, language remains an important barrier. Translating 


\section{9| Madhusudan Subedi}

concepts from one language to another may mask quite different cultural meanings and historical connotations. Researchers who have been trained in different national academic cultures often ask questions in rather different ways, use differing methods, and interpret findings in specific ways (Castles, 2001). Any specific issue should be fully understood as being embedded in much broader processes.

The research findings should be disseminated to wider audiences including a short policy brief for social media and policy makers. Historically, the communication gap between researchers and policy makers has been large, social media offer potentials to create new communication channels between researchers and policy makers, thus narrowing this gap (Grande et al., 2014). Researchers should be able to justify the policy implications they draw from such research (Davis and Howden-Chapman, 1996). Translating knowledge into improved health and effective health services can strengthen health care systems. But if the research findings are not turned into action, they will not have the impact they could and should have (Graham and Tetroe, 2007).

\section{Conclusion}

Surrogacy remains a controversial and emotional topic. Surrogacy breaks the traditional socio-cultural norms of the mother-child emotional, biological, and social attachment, the surrogate representing only a 'human incubator' and the child a 'product', without any relationship between them except for the child being the result of the woman's biological and physical labor. This means that surrogates are alienated from their bodies and motherhood (Metin, 2011).

It is hard to think that any research theme, including surrogacy, can be adequately understood within the bounds of a single academic discipline. To explore the opportunities and challenges of surrogacy in Nepal, an interdisciplinary team should be established, consisting of physicians, gynecologists, nurses, economists, psychologists, sociologists, anthropologists, and lawyers. The researchers from different disciplines can adequately understand transnational linkages, legal challenges, short-term and long-term effects of a program, various groups' access to power, the dynamics of social class and gender, cultural issues, and social and psychological 


\section{0| Madhusudan Subedi}

aspects of the surrogate mothers and their babies.

Comparative analysis is often the appropriate approach for understanding the relationships between the global and the local. However, a comparison can only be carried out effectively on the basis of detailed knowledge about specific cultures, communities, and societies. The Nepal Health Research Council, established with the specific objective of 'promoting scientific study and quality research for health in Nepal', can play an important role to coordinate a relevant team and conduct research. The team should work in a stable, professionally supportive environment with a realistic timeframe for preparing an appropriate policy on surrogacy.

The government of Nepal prepared and implemented the National Health Policy 2014 (GoN/MoHP, 2014), including also surrogacy and its provision, but it did not elaborate for whom and its processes. In general, national policies are intended to benefit their citizens. One may ask if Nepal's surrogacy policy really is a prioritized health issue serving its own citizens or rather is incorporated for the benefit of foreigners in the name of 'health tourism'? The policy should address immunizing all our children, sustainably improving the children's nutritional status and the lactating mothers, helping a poor person who is dying of kidney failure, making a concrete policy to minimize neonatal and maternal death, non-communicable disease, implementing protective measures, etc.

The mushrooming of surrogacy clinics without any proper guidelines already discriminates between the rich and the poor in practically every way. This is a crucial issue that should be discussed among academics, policy makers and planners, civil society members, and the health service providers. They should raise the concerns regarding the ethics of surrogacy, particularly because health laws are highly unregulated in Nepal. Research is urgently needed into how the negotiations between the hospitals, the intended parents, and the surrogates are done, and also the proportion of the cost to be provided by the intended parents to the hospital and to the surrogate, respectively. What are the social, emotional, and health challenges and complications faced by the surrogate mothers before and during pregnancy, and after delivery? What mechanisms have been developed to mitigate such problems?

Well-designed laws and regulations can greatly mitigate most of the potential tangible harms of surrogacy in Nepal. A proper legislation 


\section{1| Madhusudan Subedi}

should be introduced to bring some order to this blooming but

almost unregulated sector. I am not suggesting that surrogacy should not be implemented, but I indeed wish to raise the awareness of the situations in which the poor women are selling their uterus to the rich, inviting a stigmatized image.

\section{Acknowledgements}

This paper was presented in National Conference on "Sociology of Nepal: Present and Future", Kathmandu (21 November, 2015). I am indebted to Professor Emerita Marit Bakke for her continuous feedback, suggestions, and encouragement for shaping the article into this form.

\section{References}

Acero, L. (2009). The Commodification of Women's Bodies in Trafficking for Prostitution and Egg Donation. International Journal of Feminist Approaches to Bioethics, 2(1):25-32.

ACOG (2008). Committee Opinion on Surrogate Motherhood. The American College of Obstetrician and Gynecologists, 397:1-6.

Ahmari Tehran, H., Tashi, S., Mehran, N., Eskandari, N., \& Dadkhah Tehrani, T. (2014). Emotional experiences in surrogate mothers: A qualitative study. Iranian Journal of Reproductive Medicine, 12(7), 471-480.

Callahan, S. (2014). The Ethical Challenges of the New Reproductive Technologies. In Eileen E. Morrison and Beth Furlong (eds.), Health Care Ethics: Critical Issues for the 21st Century, pp, 79-96. Burlington, Ma: Jones \& Bartlett Learning.

Castles, S. (2001). Studying Social Transformation. International Political Science Review, 22(1):13-32.

Chambers, R. (1997). Whose Reality Counts? Putting the first last.

UK: Intermediate Technology Publications.

Dahal, B. (2015). Wombs for Rent. Kathmandu: The Nepali Times (30 January- 5 February 2015). Available at: http://nepalitimes. com/

article/nation/wombs-tolet-surrogacy-nepal,1991

Das, V. (2000). The Practice of Urban Transplants: Networks, Documents, Translations. In Margaret Lock, Alan Young and Alberto Cambrosio eds. Living and Working with the New Medical Technologies: Intersections of Inquiry, pp 263-287). Edinburgh, UK: Cambridge University Press. 


\section{2| Madhusudan Subedi}

Davis, P. and Howden-Chapman, P. (1996). Translating Research Findings into Health Policy. Social Science and Medicine, 43(5):865-872.

Delaney, C. (1991). The Seed and the Soil: Gender and Cosmology in Turkish Village Society. Berkeley: University of California Press.

Denzin, N. K. and Lincoln, Y. S. eds. (2005). The SAGE Handbook of Qualitative Research (Third Edition). Thousand Oaks: Sage Publications.

Durkheim, E. (1985). The Elementary Forms of Religious Life. New York: Free Press.

Edwards, J. N. (1991). New Conceptions: Biosocial Innovations and the Family. Journal of Marriage and Family, 53(2): 349360.

Graham, I. D. and Tetroe, J. (2007). How to Translate Health Research Knowledge into Effective Healthcare Action. Healthcare Quarterly, 10(3): 20-22.

Grande, D. et al. (2014). Translating Research for Health Policy: Researchers' Perceptions and Use of Social Media. Health Affairs, 33(7):1278-1285.

GoN/MoHP. National Health Policy 2014. Kathmandu: Ministry of Health and Population.

Haralambos, M. with Heald, R. (1980). Sociology: Themes and Perspectives. Delhi: Oxford University Press.

Iona Institute (2012). The Ethical Case against Surrogate Motherhood: What We Can Learn from the Law of Other European Countries. Dublin: The Iona Institute.

LeCompte M. D. and Schensul, J. J. (1999). Designing and Conducting Ethnographic Research. New Delhi, India: AltaMira Press.

Liechty, M. (2005). Carnal Economics: The Commodification of Food and Sex in Kathmandu. Cultural Anthropology, 20(1):1-38.

Mcbride, B. (2015). Complex and Troubling Dynamics in the Rise of International Surrogacy. Shared Justice. Available at: http://www.sharedjustice.org/complex and troubling dynamics in the rise of international surrogacy

Metin, S. (2011). Fooling Nature: Ethical, Social, Psychological, and Legal Aspects of Surrogate Motherhood. Law \& Justice Review, 1(3): 115-156.

Nichter, M. and Nichter, M. (1996). Anthropology and International Health: Asian Case Studies. The Netherlands: Kluwer 
Academic Publishers.

Pande, A. (2010). "“At least I am not Sleeping with Anyone": Resisting Stigma of Commercial Surrogacy in India.» Feminist Studies, 36(2):292-312.

Peng, L. (2013). "Surrogate Mothers: An Exploration of the Empirical and the Normative." American University Journal of Gender Social Policy and Law, 21(3):555-582.

Pfeifer, S. P. and Sussaman, M. B. eds.(1991). Families: Intergenerational and Generational Connections. New York: The Haworth Press.

Ritzer, G. (2000). Sociological Theory (Fifth Edition). New York: McGraw-Hill.

Roy, S. (2015). Rescuing Babies and Ignoring Surrogates in Nepal. Israel's Callousness is a Global Shame. Available at: http://www.firstpost.com/living/rescuing-babiesignoring-surrogates-nepal-israels-callousness-global- shame-2220288.html

Sammond, N. (2007). Commodities, commodity fetishism, and commodification. In George Ritzer ed., The Blackwell Encyclopedia of Sociology, pp. 607-611. Malden, USA: Blackwell Publishing Ltd.

Saxena, P., Mishra, A. and Malik, S. (2012). Surrogacy: Ethical and Legal Issues. Indian Journal of Community Medicine, 37(4): 211-213.

Schensul, S. L., Schensul, J. J. and LeCompte, M. D. (1999). Essential Ethnographic Methods. New Delhi, India: AltaMira Press.

Scherper-Huges, N. (2001). Commodity Fetishism in Organs Trafficking. Body and Society, 7(2-3): 31-62.

Sharp, L. A. (2000). The Commodification of the Body and its Parts. Annual Review of Anthropology, 29:287-328.

Subedi, M. (2001). Medical Anthropology of Nepal. Kathmandu: Udaya Books.

Subedi, M. (2010). Uterine Prolapse, Mobile Camp Approach and Body Politics in Nepal. Dhaulagiri Journal of Sociology and Anthropology, 4:21-40.

The Times of India (2011). "Womb for Sale Debates Surfaces in Nepal." Available at: http://timesofindia.indiatimes.com/ world/south-asia/Womb-for-sale-debate-surfaces-in-Nepal/

Wallbank, J. (2002). Too Many Mothers? Surrogacy, Kinship and the Welfare of the Child. Medical Law Review, 10:271-294. 
Annex I: Two Letters Issued by Chief Secretary of Nepal

\author{
बेपाल सरकार \\ सिहबरबार, काठमाडाँ : \\ कोन न : ४२१९०००, ४२१९०६ २ \\ म्याइस न ख२११०ह४
}

मश्यसचिव

मिति: २०७०/०९/०३

श्नी ग्राण्डी अन्तराष्टिय अस्पताल.

धापासी, काठमाण्डौ ।

विषय:

Surrogation सेवा शुभारम्भ भएकोमा शुभकामना ।

त्यस अस्पतालले सन् २०१४ जनवरी देखि अत्याधुनिक प्रविधिको प्रयोग गरी Surrogation प्रक्रियाबाट बिदेशी आमाहरुलाई नेपालमा ल्याई सुत्केरी गराउने सेवा प्रारम्भ गर्न लागेकोमा मलाई खुशी लागेको छ। यस प्रकारको प्रविधिवाट प्रदान गरिने सेवा नेपालमा भिग्याउन सफल भएकोमा अस्पताल परिवार तथा विशेपजहरुलाई बधाई दिन्दु । आगामी दिनमा अन्य विधाहरुमा पनि यस अस्पतालले अन्तर्रींट्रिय गुणस्तरका स्बास्थ्य सेवा प्रदान गरी नेपालको स्वास्थ्य पर्यटन (Medical Tourism) मा समेत टेवा दिन सकोस् भनी शुभकामना व्यक्त गर्द्धु । अन्य जनमुखी (विशेपगरी निम्नस्तरका जनसाधारणका लागि) स्वास्थ्य सेवाका कार्यक्रम ल्याउन सक्नुहोस, स्वास्थ्य सेवाको क्षेत्रमा तपाइहरुको सस्प्रयासमा मेरो सदा सहयोग रहने छ । धन्यवाद ।
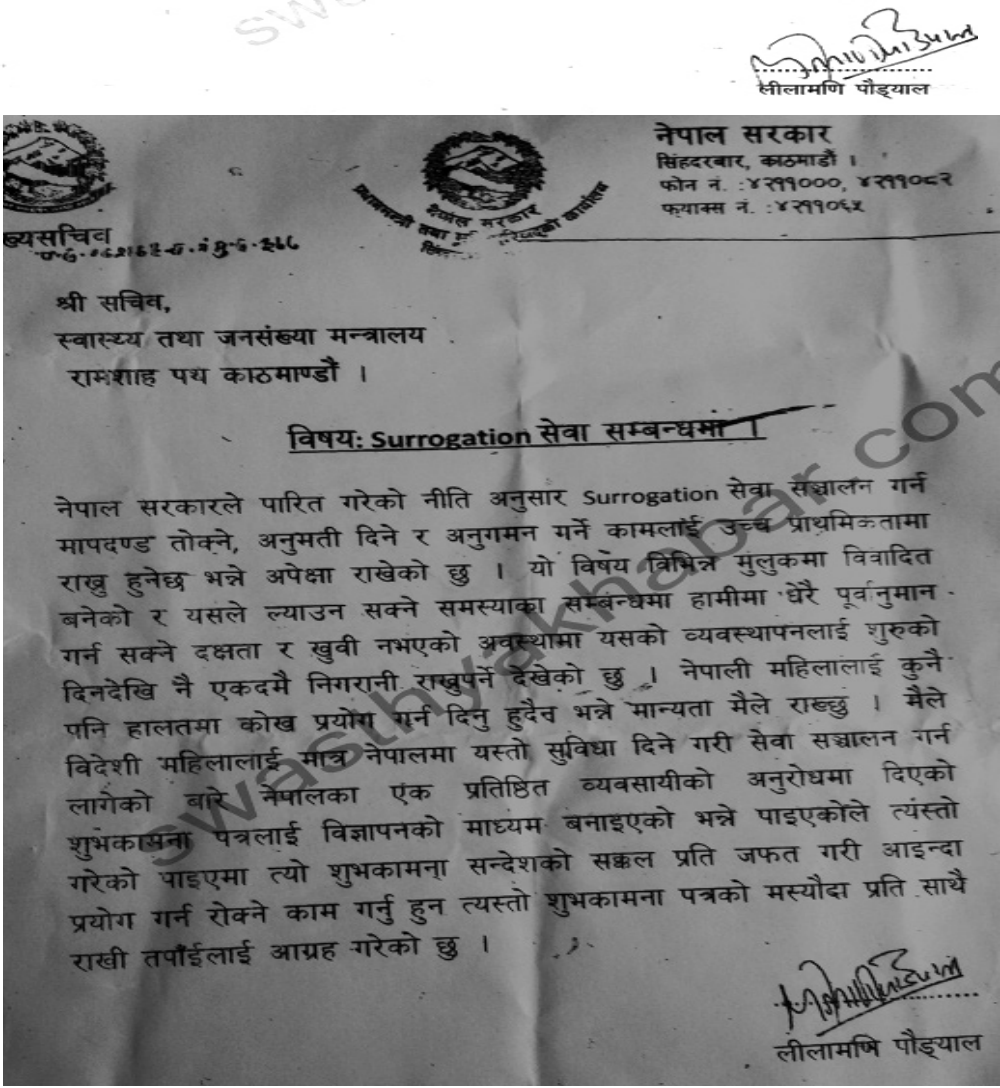


\section{5| Madhusudan Subedi}

\section{Annex II with the Supreme Court's decision}

सर्वोच अदालत एक न्यायाघीशको इजलास

सम्माननीय प्रधान न्यायाधीश श्री कल्याण श्रेष्ठ

$$
\text { ०७-พदेश }
$$

विषय - उत्प्रेषण परमादेश समेत ।

अधिवक्ता प्रविन पन्दाक समेत

१ रिट निवेदक

\section{विरुद}

प्रधानमन्न्वी तथा मन्त्रिपरिषद्को कार्यालय, सिंहदरवार, काठमाहौं समेत 9 विपक्षी

यसमा के कसो भएको हो ? निबेदकको माग बमोजिमको आदेश किन जारी हुन नपर्ने हो ? आदेश जारी गर्न नपर्ने कानून बमोजिमको कारण भए यो आदेश प्रास्त भएको मितिले बाटाको म्याद बाहेक १५ दिन भित्र सम्बन्धित प्रमाण कागज साथै राखी विपक्षी नं. १, २. ३. ४ र ४ ४ का हकमा महान्यायाधिवक्ताको कार्यालय मार्फत र विपक्षी नेपाल मेडिकल काउन्सीलका हकमा आफै बा कानून वमोजिमको प्रतिनिध्रि मार्फत लिखित जवाफ पेश गर्नु भनी यो आदेश र रीट निवेदनको नक्कल साथै राखी विपक्षीहरका नाममा सूचना स्यदि जारी गरी लिखित जवाफ प्रास भएपछि वा अवधि नाघेपहि नियमबमोजिम पेश गर्नु।

साथै अन्तरिम आदेशको संगको सम्बन्धमा विचार गर्दा, प्रजनन स्वास्थ्य मौलिक हकको बिषय भएको र जीवनलाई व्यापारको रुपमा नेपाल कानूनले मानेको अवस्था नभएकोले सरोगेसी (कोख भाडामा लिएर बच्चा जन्माउने) कार्यलाई नेपालमा मान्यता दिने नदिने ? त्यस्तो प्रक्रियाबाट जन्मने बच्चाका उपर आमा वा बाबुको के कस्तो हक रहने ? कोख भाडामा लिएको महिलाको शरीर वा जीवनको शोषण नहुने व्यवस्था कसरी गर्ने, स्वयं बच्चाको उपर आमाबाबुको कस्तो हक बा दायित्व रहने? र निजहरुको समाजमा हक के कस्तो रहने ? महिलाको कोखको व्यापारिक प्रयोजन गर्न मिल्ने नमिल्ने ? भाडामा प्रयोग गरेको भए तिनका प्रयोगको प्रभहरहु कसरी निरूपित रहने, सरोगेसीबाट जन्मेको त्यस्तो बच्चाको नागरिकता, जन्ममृत्यु घटनाको दर्ता वा प्रमाणिकता के कस्तो हुने? देशान्तरण वा स्थानान्तरण के कस्तो अवस्थामा हुने ? सरोगेसी सेबा प्रदायक वा व्यवस्थापक व्यक्ति वा संस्थाको पक्रिकरण र व्यवस्थापन तथा उत्तरदायित्वका प्रश्नहरु के हुने जस्तो विविध प्रश्रहरु यस्तो कार्यमा अन्तरनिहित हुने भै त्यसको नीतिगत कानूनी एवं संस्थागत संरचनाको सुनिश्चितताको आवश्यकतालाई उपेक्षा गरेर यस्तो गम्भीर मानवीय, कानूनी एवं

सामाजिक परिणाम भएको विपयलाई तदर्थवादी हिसावले प्रचलनमा आउन, ल्याउन वा चलाउन दिन वान्छनीय नहुने हुनाले प्रस्तुत निवेदनमा अन्तिम आदेश नभएसम्म स्वास्थ्य तथा जनसंख्या मन्त्रालयको मिति २०७१।७। २५ को पन्रद्वारा गरिएको व्यवस्था अघि नबढाउनु. तत्काल स्थगित गर्नु कार्यान्वयन नगर्नु, नगराउनु । अन्य कुनै अस्पताल, नर्सिड्र होम वा स्वास्ट्य सेवा प्रदान गर्नें निकायलाई कुने तरिकाले प्रत्यक्ष वा परोक्ष रुपमा अनुमति नदिनु नदिलाउनु । साथै यो आदेशको कार्यान्वयनको अनुगमन गरी त्यसको प्रतिवेदन प्रत्येक महिना स्वास्थ्य तथा जनसंख्या मन्त्रालयले यस अदालतमा पेश गर्नु भन्ने समेत सर्वोच्च अदालत नियमावली. २०४९ को नियम ४१(१) बमोजिम अन्तरिम आदेश जारी गरी दिएको छ। सो को सूचना विपक्षीहरुलाई दिनू । प्रस्तुत मुद्धामा उपस्थित प्रभ्नहरु सार्वजनिक महत्वको समेत देखिएको अग्राधिकार दिई पेश गर्नु । 